\title{
Economic and Environmental Effects of Using Onboard Desalinated Ballast Water from Oil and Natural Gas Trade as a Source of Water Supply for Abu Dhabi
}

\author{
Gian Vergnetti, Yanxiang Wang, and I-Tsung Tsai
}

\begin{abstract}
This paper investigates the economic and environmental effects of supplying Abu Dhabi with desalinated ballast water brought in by exporting oil tankers and liquefied natural gas (LNG) vessels on their return route from oil and natural gas trade. Traditionally, ballast water is discharged into the ocean which leads to a negative impact on marine environments. The International Maritime Organization (IMO) has developed regulations that prohibit the discharge of untreated ballast water in order to prevent these negative environmental effects. An efficient way of meeting IMO requirements would be to desalinate the ballast water and supply it domestically to local residents for consumption. In this paper, we illustrate two models. The first is a cost benefit analysis model that examines the economics of desalinating ballast water using oil tanker/LNG carrier engine waste heat under different domestic water demand scenarios. In addition to environmental benefits, results show that ballast water trading can generate cost savings of between $\$ 771.5$ million and $\$ 602.0$ million from 2012 to 2030 , depending on realized domestic water demand. The second model presents a computable general equilibrium (CGE) analysis, performed to identify GDP (Gross Domestic Product) and inter-sector production changes. An environmental analysis is built into this model to understand the impact on climate change. Flexible price and fixed price policy scenarios are considered. Results show that GDP and $\mathrm{CO}_{2}$ emissions increase under both flexible price and fixed price policy scenarios, and that implementation of a flexible price policy has more of an impact on the growth of GDP and $\mathrm{CO}_{2}$ emissions than implementation of a fixed price policy.
\end{abstract}

Index Terms-Ballast water management, desalination, environmental analysis, computational general equilibrium model.

\section{INTRODUCTION}

Abu Dhabi relies heavily on desalination of seawater due to the emirate's lack of freshwater resources. An economic boom over the past decade has resulted in substantial growth in the demand for fresh water. There are currently eight onshore desalination plants in the emirate with additional plants in the works. Desalination plants are expensive to build and operate and produce negative environmental effects. The emirate is currently seeking a sustainable approach to meeting

Manuscript received March 2, 2015; revised June 1, 2015. This work was supported in part by the Institute Center for Smart and Sustainable Systems, Masdar Institute of Science and Technology, PO Box 54224, UAE.

Yanxiang Wang and Gian Vergnetti were with the Department of Engineering Systems and Management, Masdar Institute of Science and Technology, PO Box 54224, UAE (e-mail: gvergnetti@masdarac.ae, ywang@masdarac.ae).

I-Tsung Tsai is with the Department of Engineering Systems and Management, Masdar Institute of Science and Technology, PO Box 54224, UAE (e-mail: itsai@masdarac.ae). this growing freshwater demand. Implementation of a ballast water desalination program can make a cost effective contribution to the supply of freshwater in the emirate while mitigating the harmful environmental effects of existing ballast water treatment practices on the local marine environment.

Abu Dhabi is the largest emirate in the UAE and one of the world's major oil exporting economies. The emirate exported 2.3 million barrels of oil per day (bpd) in 2009. It also has the world's fifth largest gas reserves. Oil from the emirate is exported primarily from the port of Fujairah [1]. Approximately $93 \%$ of the gas exported from Abu Dhabi goes to Japan via liquefied natural gas (LNG) carriers under long term contracts [2]. Robust oil and gas exporting activities produce large amounts of ballast water discharge into the emirate's surrounding marine environment.

According to IMO estimates, 10 billion tons of ballast water is transported and discharged around the world annually. To maintain stability, ballast tanks remain full during a ship's voyage until it reaches its port of destination, where ballast water is discharged and cargo is loaded [3]. For crude oil tankers and LNG carriers, most ballast water tanks are located in the bottom of the ship. In general, ballast water is uploaded to ships at importing ports during oil and LNG offload. The ballast water is then discharged upon return to the ship's port of export when new oil and LNG cargo is uploaded (i.e. ballast water uploaded during cargo offload in Japan is discharged during cargo upload in Abu Dhabi).

Traditionally, ships have discharged ballast water into the sea "as is" offloading non-native species and organisms that are new to local marine environments. Scientists estimate that as many as 3,000 alien species are transported by ships around the world every year. These alien species become invading species when they impair marine ecosystems [3]. Foreign organisms such as bacteria, microbes, eggs, cysts and larvae may pose a threat to local species in the host marine environment [4]-[7].

To mitigate the environmental effects of untreated ballast water discharge, the IMO has developed regulations for the shipping industry. One suggested approach is mid-ocean ballast water exchange, where ballast water is exchanged during a ship's voyage somewhere relatively closer to the port of export so that the alien (and potentially invading) species are not introduced directly into local marine environments [8], [9]. In the absence of ballast water exchange, vessels must remove the foreign organisms from ballast water before discharging it to sea. Ballast water treatment methods using chemical, heat, filtration, and ultraviolet radiation technologies have been deployed by the shipping industry, 
often at a substantial cost. In general, water desalination technologies can be implemented onboard a ship or onshore [8]. An alternative approach would be to install a system onboard the ship that desalinates ballast water using waste heat generated by the ship's engine. The desalinated ballast water would be stored in the ship's ballast water tanks until arrival at the port of destination where it would be transferred onshore to augment the local water supply.

There appear to be benefits to implementing an onboard ballast water desalination program, including:

1) An increase in the supply of fresh water while reducing demand for new onshore desalination plant capacity.

2) Reduced energy waste (utilizing waste heat from ship engines).

3) Reduced ballast water tank erosion due to the presence of desalinated water thus increasing their useful life.

4) Alleviation of damage to the local marine environment

5) Shipper compliance with IMO ballast water treatment requirements preventing potential fines as well as the cost associated with alternative ballast water treatment systems.

This paper investigates the economic effects of implementing a ballast water desalination program under three different domestic water demand scenarios.

Rapid economic and population growth in Abu Dhabi have led to increased $\mathrm{CO}_{2}$ emissions, a key contributor to climate change, as fossil fuel-based utility production has increased to meet water and electricity demands. To address this challenge the Abu Dhabi government has identified a set of measures to help achieve clean and sustainable growth [10]. In addition to the cost benefit analysis, this paper also examines the macroeconomic and environmental effects of implementing an onboard ballast water desalination program using a CGE analysis based on data from the 2007 Abu Dhabi Social Accounting Matrix (SAM).

The Abu Dhabi CGE model is calibrated with the Abu Dhabi SAM to identify Abu Dhabi's baseline economic behavior and environmental performance. The model is enhanced using the static Abu Dhabi CGE model originally created by the International Food Policy Research Institute (IFPRI) as a base [10], [11]. Four revisions are made to adapt the IFPRI model to our purposes. First, the government component is divided into two entities: the Abu Dhabi government and the Federal (UAE) government. Both entities consume commodities and services and transfer payments to one another. Second, taxes are divided into three groups: sales taxes, value-added taxes, and tariffs on imported commodities Third, it is assumed that the government subsidizes the production activities of both water and electricity. Fourth, oil export is set as an exogenous variable to account for the oil export quota set by the Organization of Petroleum Exporting Countries (OPEC).

CGE analysis has been widely applied in economic and environmental analyses of energy policies. Cai et al. study China's electricity sector carbon emissions under a restructuring of industrial sectors and technological development in the renewable energy sector [12]. Andre et al. identify the maximum economic growth rate of the Spanish economy under specific emission caps [13]. Malla examines the role of generation mix and energy intensity improvement on electricity sector carbon emissions in seven countries [14]. CGE analysis can be a reliable macroeconomic analytical approach when the required data is available.

The results of our analysis show that implementation of a ballast water desalination program will generate cost savings in the range of $\$ 771.5$ million to $\$ 602.0$ million between 2012 and 2030, depending on the realized domestic demand for water in Abu Dhabi. The amount of ballast water currently available is equivalent to $9.7 \%$ of Abu Dhabi's current domestic water production. The ballast water desalination to conventional, conventional onshore domestic desalination price ratio is calculated as $0.66977,0.66995$ and 0.65446 , respectively, under the High, Most Likely and Low water demand forecast scenarios. Abu Dhabi GDP will increase by $0.0773 \%, 0.0773 \%$ and $0.0760 \%$, respectively, under the High, Most Likely and Low water demand forecast scenarios. Implementation of a ballast water desalination program will stimulate export in other sectors as well as overall household consumption.

Carbon dioxide emissions increase by $0.0698 \%, 0.0698 \%$ and $0.0703 \%$, respectively, under the High, Most Likely and Low water demand forecast scenarios.

The remainder of this paper is organized as follows: Section II introduces the different strategies and scenarios we considered in our analysis, Section III presents the cost benefit analysis and the CGE model, Section IV outlines the data and assumptions, Section V shows the results in detail, and Section 6 discusses our conclusions.

\section{DECISIONS AND SCENARIOS}

To determine the economic benefit of supplying Abu Dhabi with desalinated ballast water from oil and natural gas trade, various ballast water desalination program strategies, water demand scenarios, domestic desalination capacity development schemes, and price policy scenarios were considered. This section discusses two ballast water desalination strategies, three water demand scenarios, two domestic desalination capacity development schemes, and two price policy scenarios.

\section{A. Treatment Strategy}

Our analysis considers two ballast water desalination program strategies to meet domestic water demand. In the first strategy, ballast water is transferred onshore for desalination at a nearby plant. In the second strategy, rather than transferring the ballast water onshore for desalination, it is desalinated onboard the oil tanker or LNG vessel during transport using waste heat recovered from the ship's engine. Upon return from oil/LNG trade to the port of export, the desalinated water is transferred onshore for polishing at a local plant and sold into the local market for consumption.

\section{B. Water Demand Scenarios \& Domestic Desalination Capacity Development Schemes}

Three water demand scenarios are considered: High, Most Likely, and Low. The baseline forecast produced by the Abu Dhabi Water and Electricity Company (ADWEC) is used as the Most Likely scenario. We consider two domestic desalination capacity development schemes. In the first 
scheme, Abu Dhabi's water demand deficit is met by new onshore desalination capacity regardless of the availability of desalinated ballast water. (Note: Preliminary analysis shows that ballast water cannot meet all of the requirements of $\mathrm{Abu}$ Dhabi's projected water demand deficit. Consequently, new desalination plant capacity must be built in order to meet demand in full). In the second scheme, domestic desalination capacity is added only when desalinated ballast water is insufficient to cover the projected water demand deficit. More specifically, new onshore desalination capacity required is set equal to the water demand deficit net of the desalinated ballast water supply.

The demand for onboard ballast water desalination $\left(D_{b w}\right)$ is calculated to identify how much ballast water will be used. This is expressed by equation 1 below:

$$
D_{b w}=\min \left(D_{\text {water }}, C_{\max }\right)
$$

where $D_{\text {water }}$ is Abu Dhabi's domestic water demand, and $C_{\max }$ is the onboard ballast water desalination capacity under the program. We assume that the Capex of onboard desalination is equivalent the Capex of onshore desalination capacity when the same technology is applied [15], [16]. The estimated Capex for the port facility includes the cost of storage, pumps, and pipelines. The estimated Opex for the port facility includes labor, pump electricity consumption, insurance, and maintenance [15].

Fig. 1 shows the projected water demand deficit, projected amount of desalinated ballast water available, and projected amount of desalinated water from new onshore plant capacity required under the Most Likely scenario. The total area reflects the water demand shortage, the blue area reflects the projected amount of desalinated ballast water available, and the green area reflects the projected amount of desalinated water from new onshore plant capacity required.

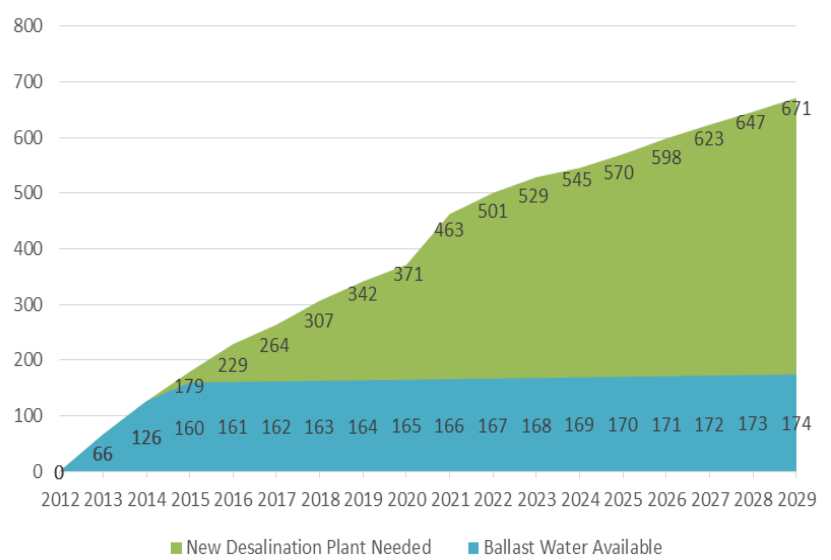

Fig. 1. Water demand deficit, projected amount of desalinated ballast water available, and projected amount of desalinated water from new onshore plant capacity required - Abu Dhabi (2012-2030) under most likely scenario (in millions of $\mathrm{m}^{3}$ ) [17]

From 2012 to 2013, water demand is met by current onshore desalination plant capacity so there is no requirement for implementation of the desalinated ballast water program or build out of new onshore desalination plant capacity. From 2014 to 2015 , there is a water deficit and we assume that desalinated ballast water is used to meet this shortage (Note: In this period, the water deficit and the projected amount of desalinated ballast water supply available are equal).From 2016 to 2030, the amount of desalinated ballast water available will not be adequate to satisfy the deficit and we assume new desalination plant capacity will be built to fill shortfall left after implementation of the ballast water desalination program.

\section{Policy Scenarios}

Implementation of the ballast water desalination program will change the cost of water production. In the model, we examine two policy scenarios: 1) Flexible Price and 2) Fixed Price. Under the flexible price policy, ballast water is introduced as an import with a flexible water price that changes according to other variables in the model. Under the fixed price policy, ballast water is introduced with a fixed price and the change in government subsidy is examined.

\section{THE MODEL}

We develop a simple model to calculate the difference between the direct cost and the opportunity cost associated with implementation of a ballast water desalination program. The economic value added in each scenario is calculated using the equations summarized as follows:

$$
\begin{gathered}
C_{n}=K+A-S-Q \\
C_{t}=M+A-Q
\end{gathered}
$$

where:

$C_{n}$ : Cost reduction for using desalinated ballast water

$C_{t}$ : Cost reduction for building new desalination plant

$K$ : Opex of onshore desalination

$A$ : Capex + Opex of treating ballast water to meet IMO requirements

$S$ : Capex + Opex of desalinating ballast water onboard ship

$Q$ : Capex + Opex of port infrastructure

$M$ : Opex advantage of desalination with ballast water versus Gulf sea water

$M$ is ignored in this analysis as we assume that there is no major cost advantage associated with Multi-Stage Flash (MSF) desalination, the dominating desalination technology deployed in the Middle East. Direct cost and opportunity cost vary depending on the water trading strategy, port configuration scenario, and onshore desalination capacity development scheme. Equation 2 calculates the cost reduction associated with using desalinated ballast water that does not require the Opex of onshore desalination, but requires the Capex and Opex of desalinating ballast water onboard a ship. Equation 3 calculates the cost reduction associated with transferring the ballast water onshore for desalination. It also incorporates the Opex advantage of desalination with ballast water versus Gulf sea water, and the Capex and Opex required for the port infrastructure.

The economic value is calculated in net present value (NPV) to provide comparable results. We collected detailed data on the cost of fuel and non-fuel related components as well as the pump efficiency rate required for onboard ballast water desalination. The net present value for a desalination strategy is determined by: 


$$
N P V=- \text { Capex }+\sum_{i=1}^{t}\left(\frac{\left[N F_{i}+B W \times P E \times B P_{i}\right] \times(1+I n)^{i}}{P B \times(1+r)^{i}}\right)
$$

where $N F=$ Non-fuel Opex (\$/year); $B W=$ ballast water to treat $\left(\mathrm{m}^{3} /\right.$ year $) ; P E=$ pump efficiency $\left(\mathrm{KWh} / \mathrm{m}^{3}\right) ; P B=$ Power generation rate with bunker fuel $(\mathrm{KWh} / \mathrm{t}) ; B P=$ bunker fuel price ( $\$ /$ ton); In = inflation rate (\%); and $r=$ interest rate (\%).

We also calculate the ballast water desalination program's impact on $\mathrm{CO}_{2}$ emissions in the following equation by multiplying industrial output from the CGE analysis with sector-specific carbon dioxide intensity:

$$
E_{\mathrm{CO}_{2}}^{S}=\frac{P_{\mathrm{CO}_{2}}^{e} \times E_{\mathrm{CO}_{2}}}{Q_{\text {benchmark }}^{a}} \times Q_{\text {actual }}^{a}
$$

where sector-specific carbon dioxide intensity equals the sector's carbon dioxide emission percentage $\left(P_{\mathrm{CO}_{2}}^{e}\right)$ times total carbon dioxide emissions ( $E_{\mathrm{CO}_{2}}$ ) divided by the sector's output quantity ( $Q_{\text {benchmark }}^{a}$ ) from the original Abu Dhabi SAM. We then derive the sector-specific carbon dioxide emissions ( $E_{\mathrm{CO}_{2}}^{S}$ ) from subsidy change by multiplying sector-specific carbon dioxide intensity by sector output quantity ( $Q_{a c t u a l}^{a}$ ) from the CGE simulation. After determining sector-specific carbon dioxide emission amounts, we sum them to arrive at total carbon dioxide emissions. Results of individual sector carbon emission intensity calculations are summarized in Table I. It should be noted that the carbon emission intensity is extremely high for the Electricity \& Water sector. The Agriculture, Crude Oil \& Natural Gas, and Manufacturing \& Construction sectors are also carbon intensive compared to other sectors.

TABLE I: SECTOR CARBON EMISSION INTENSITY

\begin{tabular}{ll}
\hline Sector & $\begin{array}{c}\text { Carbon Dioxide Intensity } \\
\text { (ton/1,000 USD) }\end{array}$ \\
\hline Agriculture & 0.256 \\
Crude Oil \& Natural Gas & 0.487 \\
Manufacture \& Construction & 0.364 \\
Electricity \& Water & 4.283 \\
Rest of Industries & 0.132 \\
\hline
\end{tabular}

The flexible price policy is also incorporated into the CGE model. Ballast water available $\left(15.57\right.$ million $\left.\mathrm{m}^{3}\right)$ as a percentage of total domestic water production $\left(160\right.$ million $\left.\mathrm{m}^{3}\right)$ is $9.7 \%$. The domestic water production price is kept at base level to reflect the real price comparison between the desalinated ballast water production price and the conventional, domestic desalinated water production price. Imported water is incorporated into the model of which ballast water is considered a component.

Under the fixed price policy, the water sector is highly subsidized and the price decrease from introducing the desalinated ballast water program is not enough to cover the entire subsidy. Money saved as a result of the price change is applied toward reduction of the subsidy and the domestic water price remains the same. The subsidy equation built into the CGE model is as follows:

$$
S_{w}=\frac{T_{S}}{P_{w} \times Q_{w}}
$$

where $s_{w}$ is the subsidy rate for water (equivalent to 0.812507061 as per the SAM), $T_{s}$ is the total subsidy for water, and $P_{w}$ and $Q_{w}$ are the price and quantity, respectively, for the water sector. We deduct the total money saved (as per the cost benefit analysis model) from the total subsidy to get the new subsidy rate. The new subsidy rates are 0.779211551, 0.779229574 and 0.77766701 , respectively, under the High, Most Likely and Low water demand forecast scenarios (Note: Were the program to be implemented, the amount of money saved would be added to government revenue).

\section{DATA AND ASSUMPTIONS}

\section{A. Data and Assumptions for the Cost Benefit Analysis}

The water demand deficit data is acquired from ADWEC [17]. Under Strategy I, all of the water demand is supplied by desalination plant capacity, so the desalination plant capacity requirement is equal to the water demand deficit. Under Strategy II, we assume desalinated ballast water based on oil and natural gas export volume is applied toward meeting the water demand deficit. Annual growth rates for Middle East oil and natural gas export are applied based on projections in the British Petroleum (BP) Energy Outlook 2035 [18]. The annual growth rates are $0.624 \%$ and $0.601 \%$, respectively, for oil and natural gas export from 2012 to 2030. Since the United Arab Emirates (UAE) is a member of OPEC and Abu Dhabi is the major exporter of the UAE, we assume growth rates for oil and natural gas export in Abu Dhabi are the same as those in the rest of the Middle East. The desalinated ballast water available is that which can be derived from the associated oil and natural gas trade as projected in Fig. 2. We assume that in $2012,138,801,533.5 \mathrm{~m}^{3}$ of desalinated ballast water may be derived from oil export and 16,910,175 $\mathrm{m}^{3}$ from natural gas export [19]). We know that the desalinated ballast water program cannot cover all of the water demand deficit and that new onshore desalination plant capacity must be built in order to meet the defecit in full. The projected amount of desalinated water from new onshore plant capacity required is calculated by deducting the projected amount of desalinated ballast water available from the projected water demand deficit. Data used in the analysis are summarized in Table II with corresponding reference.

\section{TABLE II: DATA AND ASSUMPTIONS}

\begin{tabular}{lll}
\hline \multicolumn{1}{c}{ Cost Item } & \multicolumn{1}{c}{ CAPEX } & \multicolumn{1}{c}{ OPEX } \\
\hline $\begin{array}{l}\text { Onshore Desalination } \\
\text { (Conventional) }\end{array}$ & $\$ 920,876,346.12[20]$ & $\$ 0.26 / \mathrm{m}^{3}[21]$ \\
$\begin{array}{l}\text { Onboard Desalination } \\
\text { Ballast Water Treatment }\end{array}$ & $\$ 1,544,812,093[16]$ & $\$ 0.36 / \mathrm{m}^{3}[21]$ \\
System (Conventional): & $\$ 36,000,000[16]$ & $\$ 0.08 / \mathrm{m}^{3}[16]$ \\
Port Infrastructure: & P $_{\text {Desal \& Polish Plant: }}$ & P Desal \&Polish Plant: \\
& $\$ 3,464,200$ & $\$ 0.001664$ \\
& PPolish Khalifa Port: & P Polish Port: $\$ 0.001664$. \\
& $\$ 3,464,200[16]$ & {$[16]$} \\
\hline
\end{tabular}


Assumptions are as follows:

- Natural Gas Export Rate Equivalent: 270 bcf [4]

- Vessel visits/year: 12

- Time horizon: 19 years

- Interest rate: $8 \%$

- Inflation rate: $2 \%$

- Project start date: 2012

- Probability of carbon crediting: 50\% [16]

- Desalination technology benchmark: MSF [16]

- Onboard desalination system $=\$ 4,500,000 /$ ship [16]

- Bunker fuel price $=\$ 600 /$ ton $[16]$

- Pump electricity/fuel conversion rate $=5000 \mathrm{kwh} / \mathrm{ton}[16]$

- Port Storage and Polishing capacity $=\$ 1,000,000$

- Port Pump = \$10,000 /pump

- Port Pump efficiency rate $=1.5 \mathrm{KWh} / \mathrm{m}^{3}$

- Port Pipeline $=\$ 200 / \mathrm{m}$

Onshore desalination capacity capital expenditure is estimated based on the Capex for treatment capacity of $400,000,000 \mathrm{~m}^{3} /$ day [16]. Onshore desalination operating expenditure is estimated based on the average cost of desalination technologies used in the UAE, which include Multi-Stage Flash (MSF), Reverse Osmosis (RO), and Multi Effect Desalination (MED). The Capex for an onboard ballast water desalination system is estimated to be $\$ 4,500,000 /$ ship. Onboard ballast water desalination Opex is estimated to be $\$ 0.36 / \mathrm{m}^{3}[15]$.

\section{B. Data and Assumptions for the CGE Analysis}

To calibrate the CGE model for economic analysis, we used the 2007 Social Accounting Matrix (SAM) compiled by the Abu Dhabi Council of Economic Development (ADCED) The Abu Dhabi SAM consists of 13 economic sectors: Electricity, Gas, \& Water; Crude Oil; Natural Gas; Quarrying; Petrochemical; Other Manufactured Products; Wholesale, Retail Trade \& Repairing Services; Transport Storage \& Communication; Social, Personal, Governmental \& Domestic Services; Financial Corporation Services; Hotels \& Restaurants; Business Services; and Real Estate. The SAM also contains information about input-output data for commodities as intermediate inputs for economic activities.

Since there are no official individual sector carbon emissions data available for Abu Dhabi, we use the 2005 UAE Greenhouse Gas (GHG) inventory data, as reported by the UAE 3rd National Communications with UNFCCC. The UAE GHG inventory data includes individual sector carbon emissions as a percentage of total emissions for 5 sectors. The sector carbon emissions as a percentage of total carbon emissions are 1\% for Agriculture, 14\% for Oil \& Gas, $37 \%$ for Manufacturing \& Construction, 33\% for Electricity, and $15 \%$ for the Rest of the Industry (ROI) Sectors. Given that sector carbon emission intensity is determined primarily by technologies, and the technologies used in different emirates of the UAE tend to be similar across emirates, it is reasonable to assume that the sector carbon intensities of the UAE and Abu Dhabi are very similar.

To match economic activity with carbon emission data in Abu Dhabi, we rearrange and combine the economic sector classifications used in the SAM and GHG inventory. We combine an expanded 14 SAM economic activities with 4 economic activities from the GHG inventory. We disaggregate the Electricity, Gas and Water sector to form two separate sectors, 1) the Electricity \& Gas sector and 2) the Water sector, based on the sector percentage share of total expenditure in the 1995 Abu Dhabi Input-Output table. This is done to separate the effects of the electricity and water subsidy reduction. While construction and manufacturing are classified as one sector in the carbon emission data, they are treated as separate sectors in the CGE analysis as construction is a non-traded sector while manufacturing is a traded one. The Agriculture, Livestock and Fishing sector remains the same. Crude Oil and Natural Gas are combined to form one sector as is Quarrying, Petrochemicals and Other Manufactured products. All of the remaining sectors are combined into the Rest of the Industry sector.

\section{RESUlts}

\section{A. Cost Analysis}

The total water demand requirements for conventional desalination plant capacity and the ballast water desalination program under different strategies from 2012 to 2030 are listed in Table III. Under Strategy I, desalinated water demand is met entirely by conventional, onshore desalination plant capacity in the amount of 9,298.77 million $\mathrm{m}^{3}, 7,030.86$ million $\mathrm{m}^{3}$, and 4,081.58 million $\mathrm{m}^{3}$ respectively under the High, Most Likely and Low water demand forecast scenarios. Under Strategy II, 6,406.57 million $\mathrm{m}^{3}$, 4,337.24 million $\mathrm{m}^{3}$, and $1,920.84$ million $\mathrm{m}^{3}$ of desalinated water demand is met by domestic, conventional onshore desalination, respectively under the High, Most Likely and Low water demand forecast scenarios. 2,892.2 million $\mathrm{m}^{3}, 2,693.62$ million $\mathrm{m}^{3}$, and $2,160.74$ million $\mathrm{m}^{3}$ of desalinated water demand is met by the ballast water desalination program under these same scenarios respectively. Obviously the assumptions we make have a direct impact on our analysis results. Uncertainties such as future water demand, natural gas price, and bunker fuel price may also affect the economic value added. Here we focus on the major uncertainties in order to provide benchmarking. As shown in Table IV, the unit prices of each cubic meter of water from conventional onshore desalination are $\$ 0.80775 / \mathrm{m}^{3}, \$ 0.80743 / \mathrm{m}^{3}$, and $\$ 0.80635 / \mathrm{m}^{3}$ and the unit prices of each cubic meter of onboard, desalinated ballast water are $\$ 0.54101 / \mathrm{m}^{3}, \$ 0.54094 / \mathrm{m}^{3}$, and $\$ 0.52772 / \mathrm{m}^{3}$. respectively under the three water demand forecast scenarios considered. A cubic meter of water under Strategy I is more costly than a cubic meter under Strategy II. Table V shows the total cost and cost advantage of each strategy under the three water demand forecast scenarios as calculated by multiplying the cost of each cubic meter of water by total water demand requirements. Implementation of Strategy II vs. Strategy I will save $\$ 771.5$ million, $\$ 717.8$ million, and $\$ 602.0$ million respectively under the different water demand forecast scenarios (High, Most Likely and Low).

\section{B. Macroeconomic Analysis}

Under a flexible price policy and the most likely water demand scenario, implementing the ballast water desalination program increases GDP by $0.077 \%$. The $0.207 \%$ bump in export revenue contributes most to this increase. Under a 
fixed price policy and the most likely water demand scenario, implementing the ballast water desalination system increases GDP by $0.023 \%$. In this case the $0.266 \%$ bump in government consumption contributes most to the increase.

TABLE III: DEMAND MET By CONVENTIONAL, ONSHORE DESALINATION PlaNT CAPACITY AND BALLAST WATER DESALINATION PROGRAM UNDER

\begin{tabular}{lccc}
\multicolumn{2}{c}{ DIFFERENT STRATEGIES FOR 18} & YEARS (IN MILLIONS OF M ${ }^{3}$ ) \\
\hline \multirow{2}{*}{ Scenario } & Strategy I & \multicolumn{2}{c}{ Strategy II } \\
& Conventional & Conventional & Ballast Water \\
\hline High & 9298.77 & 6406.57 & 2892.2 \\
Most Likely & 7030.86 & 4337.24 & 2693.62 \\
Low & 4081.58 & 1920.84 & 2160.74 \\
\hline
\end{tabular}

TABLE IV: UNIT PRICE PER CUBIC METER OF WATER UNDER DIFFERENT STRATEGIES

\begin{tabular}{cll}
\hline Scenario & Conventional & Ballast Water \\
High & $\$ 0.80775 / \mathrm{m}^{3}$ & $\$ 0.54101 / \mathrm{m}^{3}$ \\
Most Likely & $\$ 0.80743 / \mathrm{m}^{3}$ & $\$ 0.54094 / \mathrm{m}^{3}$ \\
Low & $\$ 0.80635 / \mathrm{m}^{3}$ & $\$ 0.52772 / \mathrm{m}^{3}$ \\
\hline
\end{tabular}

TABLE V: COST AdVANTAGE OF EACH STRATEGY UNDER EACH WATER DEMAND FORECAST SCENARIO (IN MILLIONS OF US DOLLARS)

\begin{tabular}{cccc}
\hline Scenario & Strategy I & Strategy II & $\begin{array}{c}\text { Cost Advantage by } \\
\text { using Strategy II }\end{array}$ \\
\hline High & $\$ 7,511.1$ & $\$ 6,739.6$ & $\$ 771.5$ \\
Most Likely & $\$ 5,676.9$ & $\$ 4,959.1$ & $\$ 717.8$ \\
Low & $\$ 3,291.2$ & $\$ 2,689.1$ & $\$ 602.0$ \\
\hline
\end{tabular}

The domestic production price for all sectors decreases as a result of introducing the ballast water desalination system under a flexible price policy which leads to increased consumption. The electricity, manufacturing and construction sectors experience the largest increase. Household consumption in all sectors increases due to the lower prices in all sectors. The water sector experiences the most growth increasing by $2.649 \%$. Electricity production, which is very water intensive, benefits from a reduction in the price of water. This leads to higher consumption of electricity (an increase of $0.210 \%$ ).

Household consumption in all sectors decreases under a fixed price policy. Household consumption changes by sector are presented in Table VI.

As outlined in Table VII, except for in the cases of manufacturing import and domestic water production (under all policies and water demand scenarios) and agriculture import and domestic construction production (under the fixed price policy), domestic production, import and export levels for each sector increase under the different policy and water demand scenarios. Export levels increase in all sectors. Export levels for agriculture, manufacturing, and rest of industry increase by $0.403 \%, 0.523 \%$ and $0.428 \%$, respectively, under the flexible price policy. Manufacturing imports decrease due to increased domestic production and low growth in the composite good supply.

TABLE VI: Sector Percentage Change of Household Consumption

\begin{tabular}{|c|c|c|c|c|c|c|}
\hline \multirow{2}{*}{ Sector } & \multicolumn{3}{|c|}{ Flexible Price Policy } & \multicolumn{3}{|c|}{ Fixed Price Policy } \\
\hline & High & Most Likely & Low & High & Most Likely & Low \\
\hline Agriculture & $0.066 \%$ & $0.066 \%$ & $0.066 \%$ & $-0.027 \%$ & $-0.027 \%$ & $-0.028 \%$ \\
\hline Manufacturing & $0.013 \%$ & $0.013 \%$ & $0.013 \%$ & $-0.005 \%$ & $-0.005 \%$ & $-0.005 \%$ \\
\hline Electricity & $0.211 \%$ & $0.210 \%$ & $0.213 \%$ & $-0.056 \%$ & $-0.056 \%$ & $-0.058 \%$ \\
\hline Water & $2.650 \%$ & $2.649 \%$ & $2.952 \%$ & $-0.061 \%$ & $-0.061 \%$ & $-0.064 \%$ \\
\hline Construction & $0.131 \%$ & $0.131 \%$ & $0.131 \%$ & $-0.044 \%$ & $-0.044 \%$ & $-0.046 \%$ \\
\hline Rest of Industry & $0.161 \%$ & $0.161 \%$ & $0.161 \%$ & $-0.063 \%$ & $-0.063 \%$ & $-0.066 \%$ \\
\hline
\end{tabular}

TABLE VII: DOMESTIC PRODUCTION, IMPORT AND EXPORT PERCENTAGE CHANGES

\begin{tabular}{|c|c|c|c|c|c|c|c|}
\hline \multirow{2}{*}{ Sector } & & \multicolumn{2}{|c|}{ Flexible Price Policy } & \multicolumn{4}{|c|}{ Fixed Price Policy } \\
\hline & & High & Most Likely & Low & High & Most Likely & Low \\
\hline \multirow[t]{3}{*}{ Agriculture } & Production & $0.178 \%$ & $0.178 \%$ & $0.183 \%$ & $0.007 \%$ & $0.007 \%$ & $0.007 \%$ \\
\hline & Export & $0.403 \%$ & $0.403 \%$ & $0.419 \%$ & $0.028 \%$ & $0.028 \%$ & $0.030 \%$ \\
\hline & Import & $0.044 \%$ & $0.044 \%$ & $0.041 \%$ & $-0.006 \%$ & $-0.006 \%$ & $-0.006 \%$ \\
\hline \multirow[t]{3}{*}{ Manufacture } & Production & $0.171 \%$ & $0.171 \%$ & $0.171 \%$ & $0.029 \%$ & $0.029 \%$ & $0.031 \%$ \\
\hline & Export & $0.523 \%$ & $0.523 \%$ & $0.522 \%$ & $0.070 \%$ & $0.070 \%$ & $0.074 \%$ \\
\hline & Import & $-0.039 \%$ & $-0.039 \%$ & $-0.039 \%$ & $-0.002 \%$ & $-0.002 \%$ & $-0.002 \%$ \\
\hline Electricity & Production & $0.108 \%$ & $0.108 \%$ & $0.110 \%$ & $0.025 \%$ & $0.025 \%$ & $0.026 \%$ \\
\hline Water & Production & $-10.82 \%$ & $-10.82 \%$ & $-10.82 \%$ & $-0.03 \%$ & $-0.03 \%$ & $-0.03 \%$ \\
\hline \multirow[t]{2}{*}{ Construction } & Production & $0.017 \%$ & $0.017 \%$ & $0.017 \%$ & $-0.024 \%$ & $-0.024 \%$ & $-0.025 \%$ \\
\hline & Production & $0.183 \%$ & $0.183 \%$ & $0.183 \%$ & $0.006 \%$ & $0.006 \%$ & $0.007 \%$ \\
\hline \multirow[t]{2}{*}{ Rest of Industry } & Export & $0.428 \%$ & $0.428 \%$ & $0.428 \%$ & $0.069 \%$ & $0.069 \%$ & $0.073 \%$ \\
\hline & Import & $0.036 \%$ & $0.036 \%$ & $0.036 \%$ & $0.096 \%$ & $0.096 \%$ & $0.101 \%$ \\
\hline
\end{tabular}

\section{Environmental Analysis}

Introduction of the desalinated ballast water program will bring environmental benefits as well, such as improvement in Abu Dhabi's marine eco-system. Monetizing the environmental benefits is beyond the scope of this paper, however, positive effects, such as preservation of coral reefs and marine species will be realized should the program be implemented.

Under a flexible price policy, results from our climate change analysis show that carbon dioxide emissions will increase by $0.0698 \%, 0.0698 \%$ and $0.0704 \%$ under the 
different water demand forecast scenarios respectively. Under a fixed price policy, carbon dioxide emissions will increase by $0.00835 \%, 0.00834$, and $0.00874 \%$ respectively. The increase in carbon dioxide emissions is due mainly to increased domestic production in non-water sectors. Introduction of the ballast water desalination program reduces the water price which reduces the cost of water for other sectors and leads to increased consumption. This increased consumption leads to an increase in carbon dioxide emissions. As shown in Table VII, under the flexible price policy, domestic production increases most in the agriculture, manufacturing and rest of industry sectors. Under the fixed price policy, domestic production increases most in the manufacturing and electricity sectors. Should the Abu Dhabi government attempt to reduce water consumption, policy should focus first on those sectors that reduce carbon dioxide emissions most efficiently.

\section{Results for the Period between 2012 and 2030}

We analysed the water demand shortage data under the most likely scenario during three stages over 19 years. Comprehensive time series results are presented below. During the first stage, from 2012 to 2013, water supply is higher than water demand. During the second stage, from 2014 to 2015 , there is a water demand shortage and the entire shortage amount is met by implementation of the ballast water desalination program. During the third stage, from 2016 to 2030 , the water demand shortage cannot be met entirely by the ballast water desalination program and new desalination plant capacity must be built. In Fig. 2, we take the increased rate of GDP, $\mathrm{CO}_{2}$, and domestic household water consumption under the flexible price policy and project the data.

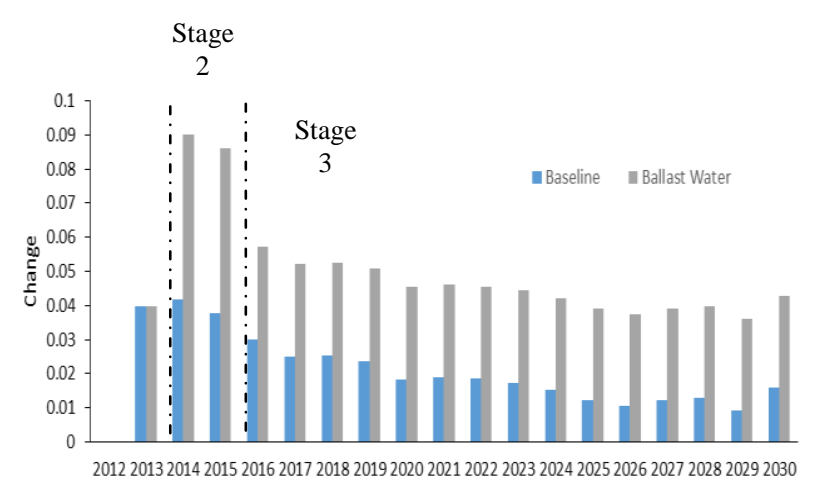

Fig. 3. Domestic household consumption marginal growth rate change from 2012 to 2030 .

In the first stage, GDP, $\mathrm{CO}_{2}$ emissions and domestic household consumption will remain the same. In the second stage, the ballast water desalination program is introduced which will cause GDP, $\mathrm{CO}_{2}$ emissions, and domestic household consumption to increase. Fig. 3 shows that initially the rate of $\mathrm{CO}_{2}$ emission increase is higher than the rate of GDP increase. During the third stage, new desalination plant capacity is built. GDP, $\mathrm{CO}_{2}$ emissions, and domestic household consumption continue to increase, but the rate of increase for $\mathrm{CO}_{2}$ emissions starts to decelerate, while the rate of increase for GDP acellerates. Fig. 2 shows that domestic household consumption grows less in the third stage than the second.
A summary of GDP and $\mathrm{CO}_{2}$ emissions growth rates are presented in Table VIII.

TABLE VIII: SUMMARY OF GDP AND $\mathrm{CO}_{2}$ EMISSIONS GROWTH RATES UNDER DIFFERENT POLICY AND WATER DEMAND SCENARIOS

\begin{tabular}{|c|c|c|c|c|c|}
\hline \multicolumn{3}{|c|}{ Flexible Price Policy } & \multicolumn{3}{|c|}{ Fixed Price Policy } \\
\hline High & Most Likely & Low & High & Most Likely & Low \\
\hline $\mathrm{CO}_{2} \quad 0.0698 \%$ & $0.0698 \%$ & $\begin{array}{c}0.0704 \\
\%\end{array}$ & $0.0084 \%$ & $0.0083 \%$ & $0.0087 \%$ \\
\hline GDP $0.0773 \%$ & $0.0773 \%$ & $\begin{array}{c}0.0760 \\
\%\end{array}$ & $0.0228 \%$ & $0.0228 \%$ & $0.0238 \%$ \\
\hline
\end{tabular}

Broadly speaking, the flexible price policy has more of an impact on the growth of GDP and $\mathrm{CO}_{2}$ emissions than the fixed price policy.

\section{CONCLUSION}

Our analysis shows that implementation of the ballast water desalination program generates savings of $\$ 771.5$ million, $\$ 717.8$ million, and $\$ 602.0$ million, respectively under the High, Most Likely, and Low water demand forecast scenarios. In summary, implementation of the ballast water desalination program in Abu Dhabi is economically feasible.

At the macroeconomic level, under the flexible price policy, GDP increases by $0.0773 \%, 0.0773 \%$ and $0.0760 \%$ respectively under the different water demand forecast scenarios. Household consumption, domestic production, export and import increase at various levels (except for domestic water production due to replacement by the ballast water desalination program) and manufacturing import (due to the high domestic production growth rate and low composite good supply rate).

In addition to the economic benefit, ballast water desalination will also contribute to environmental and health gains. The results of our analysis indicate that ballast water-based water trade has the potential to contribute to cost efficient water supply in Gulf Cooperation Council (GCC) countries. It may also contribute to the welfare of the tourism, fishing and shipping industries. Future studies may explore additional benefits to these sectors.

Our climate change analysis shows that carbon dioxide emissions increase by $0.0698 \%, 0.0698 \%$ and $0.0704 \%$ respectively under the different water demand forecast scenarios. This is a result of increased consumption due to the reduced cost of water. In order to mitigate increased carbon dioxide emissions caused by implementation of the ballast water desalination program, corresponding policy should be enacted to limit consumption and encourage people to use water resources smartly and efficiently. Focus should be on the agriculture, manufacturing, and rest of industry sectors since domestic production increases experiences the largest increase in these sectors

GDP and $\mathrm{CO}_{2}$ emissions under the fixed price policy are also examined. GDP increases by $0.0228 \%, 0.0228 \%$ and $0.0238 \%$ respectively and carbon dioxide emissions increase by $0.0084 \%, 0.0083 \%$ and $0.0087 \%$ respectively under the different water demand forecast scenarios. The flexible price policy has more of an impact on the growth of GDP and $\mathrm{CO}_{2}$ emissions than the fixed price policy.

Global oil and natural gas demand are projected to increase 
rapidly as is export of oil and natural gas from Abu Dhabi. This implies potential for implementation of the ballast water desalination program. Further analysis can be done to analyze the long term impact of a ballast water desalination program in Abu Dhabi and the GCC region more broadly.

\section{ACKNOWLEDGMENT}

We would like to thank the Abu Dhabi Council of Economic Development for providing the 2007 Abu Dhabi Social Accounting Matrix data, and the Masdar Initiative for providing financial support for this research.

\section{REFERENCES}

[1] IEA, Oil market Report, IEA, 2011

[2] Abu Dhabi's gas dilemma, Economic Review, Abu Dhabi, 2010.

[3] MarineTech, "Ballast water treatment systems on marine vessels," 2013.

[4] S. Gollasch, "Removal of barriers to the effective implementation of ballast water control and management measures in developing countries," IMO MEPC Ballast Water Working Group, Short Version, 1998.

[5] D. M. Anderson et al., "The ecology and oceanography of harmful algal blooms," The American Society of Limnology and Oceanography, 1997.

[6] C. L. Hewitt and M. L. Campbell, "Mechanisms for the prevention of marine bioinvasions for better biosecurity," Marine Pollution Bulletin, vol. 55, no. 7, pp. 395-401, 2007.

[7] L. A. Drake, M. A. Doblin, and F. C. Dobbs, "Potential microbial bioinvasions via ships' ballast water, sediment, and biofilm," Marine Pollution Bulletin, vol. 55, no. 7, pp. 333-341, 2007.

[8] D. Boklor et al., "Design and implementation of a continuous microwave heating system for ballast water treatment," Environmental Science \& Technology, vol. 42, no. 11, pp. 4121-4127, 2008.

[9] N. N. Pereira and H. L. Brinati, "Onshore ballast water treatment: A viable option for major ports," Marine Pollution Bulletin, 2012.

[10] Y. Wang et al., "Economic and environmental effects of electricity and water subsidy reduction in Abu Dhabi - A coumputational general equilibrium analysis," Utility Policy, 2013.

[11] H. Lofgren, R. L. Harris, and S. Robinson, "A standard computable general equilibrium (CGE) model in GAMS," Washinton. DC: International Food Policy Research Institute, 2002.

[12] W. J. Cai et al., "Scenario analysis on $\mathrm{CO}_{2}$ emissions reduction potential in China's electricity sector," Energy Policy, pp. 6445-6456, 2007.

[13] F. J. Andre and M. A. Cardenete, "Obtaining efficient economic and environmental policies for the Spanish economy," The Emipirical Economics Letters, 2010.

[14] S. Malla, " $\mathrm{CO}_{2}$ emissions from electricity generation in seven Asia-Pacific and North American Countries: A decomposition analysis," Energy Policy, pp. 1-9, 2009.
[15] T. Mezher et al., "Techno-economic assessment and environmental impacts of desalination technologies," Desalination, vol. 266, no. 1, pp. 263-273, 2011

[16] G. Vergnetti et al., "Integration of ballast water treatment and fresh water production for Abu Dhabi: An economic assessment," presented at the Conference on Sustainable Business in Asia, Bangkok, 2012.

[17] ADWEC, "Statement of future capacity requirement 2008 - 2030," Abu Dhabi, ADWEC, 2008, p. 82.

[18] BP, "BP energy outlook 2035," BP, 2014.

[19] SCAD, "Statistical year book of Abu Dhabi," Abu Dhabi, SCAD, 2013, pp. 73-74.

[20] F. Revilla, "Desalination markets 2010," Global Water Intelligence, 2010.

[21] R. Borsani and S. Rebagliati, "Fundamentals and costing of MSF desalination plants and comparison with other technologies," Desalination, vol. 182, no. 1, pp. 29-37, 2005.

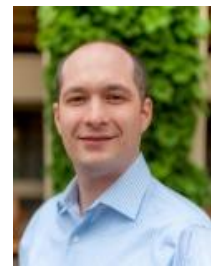

Gian Vergnetti is an analyst at EnerTech Capital. He is a leading energy technology-focused investment firm based in Philadelphia, PA, USA. Prior to EnerTech, Gian conducted research as a U.S. fulbright scholar at Masdar (Abu Dhabi Future Energy Company) in Masdar City, Abu Dhabi, United Arab Emirates, where his work focused on investments in the energy and natural resources space. Prior to that, he was a specialist in the alternative investments group at Merrill Lynch \& Co. Gian received a BS in international business from The University of Scranton.

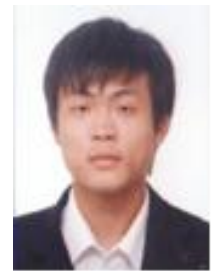

Yanxiang Wang was born in Shanghai China, on Oct. 11, 1989. He received his master degree at Masdar Institute of Science and Technology in Abu Dhabi, United Arab Emirates (UAE). He is a consultant in sustainability team in PricewaterhouseCoopers $(\mathrm{PwC})$ Prior to joining $\mathrm{PwC}$, he worked as an assistant researcher in engineering systems and management program at Masdar Institute of Science and Technology. His research interests include low carbon analysis, economic modeling and optimization.

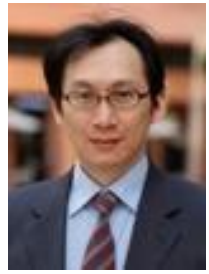

I-Tsung Tsai is an assistant professor in the engineering systems and management program at the Masdar Institute. Prior to joining Masdar Institute, Dr. Tsai served as a water strategy consultant for the Singapore government and was a visiting scholar to the Institute of Financial Research and Management, India in 2006. He holds a PhD in risk management from the Massachusetts Institute of Technology (2007), a MS in construction engineering and management from the Massachusetts Institute of Technology (2002), and a MS in transportation engineering from the National Cheng-Kung University (1999). 